\title{
A new anthophilic species of Drosophila Fallén belonging to the bromeliae group of species (Diptera, Drosophilidae)
}

\author{
Alessandra de A. R. da Silva \& Marlúcia B. Martins \\ Coordenação de Zoologia, Museu Paraense Emilio Goeldi/MCT. Caixa Postal 399, 66040-170 Belém, Pará, Brasil. E-mail: \\ marlucia@museu-goeldi.br
}

\begin{abstract}
Drosophila speciosa sp. nov. from: Belém, Pará, Brazil, is described and morphologically compared to a closely related species, D. aguape Val \& Marques, 1996. Adult specimens of $D$. speciosa sp. nov. were collected while visiting T. speciosum Willd. ex Spreng. flowers in EMBRAPA's Theobroma Linnaeus germoplasm collections (113 individuals) in Belém and in Caxiuanã Scientific Station, in Melgaço, Pará, Brazil (four individuals). Emergent were obtained from $T$. speciosum flowers in both localities being four adults in Caxiuanã and 532 in EMBRAPA. Other eight emergencies were registered from Passiflora edulis Sims flowers in Curuçá, Pará, Brazil.

KEY WORDS. Anthophilic flies, drosophilids, pollination, Theobroma speciosum.
\end{abstract}

RESUMO. Drosophila speciosa sp. nov. de Belém, Pará, Brasil, é descrita e comparada morfologicamente com uma espécie estreitamente relacionada, $D$. aguape Val \& Marques, 1996. Os adultos de $D$. speciosa sp. nov. foram coletados visitando as flores de Theobroma speciosum Willd. ex Spreng. na coleção de germoplasma de Theobroma Linnaeus da Empresa Brasileira de Pesquisa Agropecuária da Amazônia Oriental - EMBRAPA (113 indivíduos) em Belém e na Estação Científica Ferreira Penna em Caxiuanã, Melgaço, Pará, Brasil (quatro indivíduos). Os emergentes foram obtidos das flores de $T$. speciosum em ambas localidades, quatro adultos em Caxiuanã and 532 na EMBRAPA. Outros oito emergentes foram observados em flores de maracujá (Passiflora edulis Sims) em Curuçá, Pará, Brasil. PALAVRAS CHAVE. Drosofilídeos, moscas antofílicas, polinização, Theobroma speciosum.

The flower breeding Drosophila Fallén, 1823 species are poorly studied in the Neotropics. Two species groups of the subgenus Drosophila: Drosophila (D.) flavopilosa Frey, 1919 (WheELer et al. 1962) and Drosophila (D.) bromeliae Sturtevant, 1921 (PATTERSON $\&$ STONE 1952) - are associated with living flowers. Species of the flavopilosa group are known only from the flowers of the genera Cestrum Linnaeus e Sessea Ruy \&Pav. (Solanaceae), whereas species of the bromeliae group are more generalists, visiting the living and decaying flowers of Convolvulaceae (Patterson \& Stone 1952), Pontederiaceae (VAL \& Marques 1996), and Aristolochiaceae (SAKAI 2002). This paper describe a new specie of Drosophila founded visiting sapromiophilic flowers of Theobroma speciosum Willd. ex Spreng. in Belém, Pará, Brazil.

\section{MATERIAL AND METHODS}

The preparation of the male and female genitalia followed the methodology of Wheeler \& Kambysellis (1966) and Kaneshiro (1969). Male terminalia terminology follows VaL (1982) and VAL \& Marques (1996).

All strain has been maintained of the drosophilids laboratory in the Museu Paraense Emílio Goeldi, Belém, Pará.

\section{Drosophila speciosa sp. nov.}

Figs $1-9,11$ and 12

Holotype: male; obtained 05 July 2001 from isofemale strain N06012.01 from inflorescence of Theobroma speciosum collected: Brazil, Pará, Belém, EMBRAPA/CPATU germoplasm collection, $01^{\circ} 20^{\prime} \mathrm{S}, 48^{\circ} 03^{\prime} \mathrm{W}$; A.A.R. da Silva, 14 June 2001. Paratypes 38: 8 females and 13 males from strain N06012.01, 1 female and 6 males obtained 23 July 2002 from isofemale strain O05011.01, and 1 female obtained 09 September 2002 from isofemale strain O11002. Four females and five males (strain N09050) obtained 19 June 2001 emerging from flowers of Passiflora edulis Sims collected in Curuçá, Pará, Brazil.

Genitalia from seven paratypes of strain O05011.01 were removed and dissected. The single female and one of the male of strain O05011.01 were illustrated. All type specimens are deposited in the Museu Paraense Emílio Goeldi (MPEG), Belém, Pará, Brazil.

Small, yellow flies (Fig. 1). Body length (pinned specimens) $1.5-1.7 \mathrm{~mm}$ (male), 1.7-2.0 $\mathrm{mm}$ (female). Head: antennae yellow; arista brown, usually with 4 dorsal and 2 ventral branches in addition to the distal fork. Front yellow, area be- 

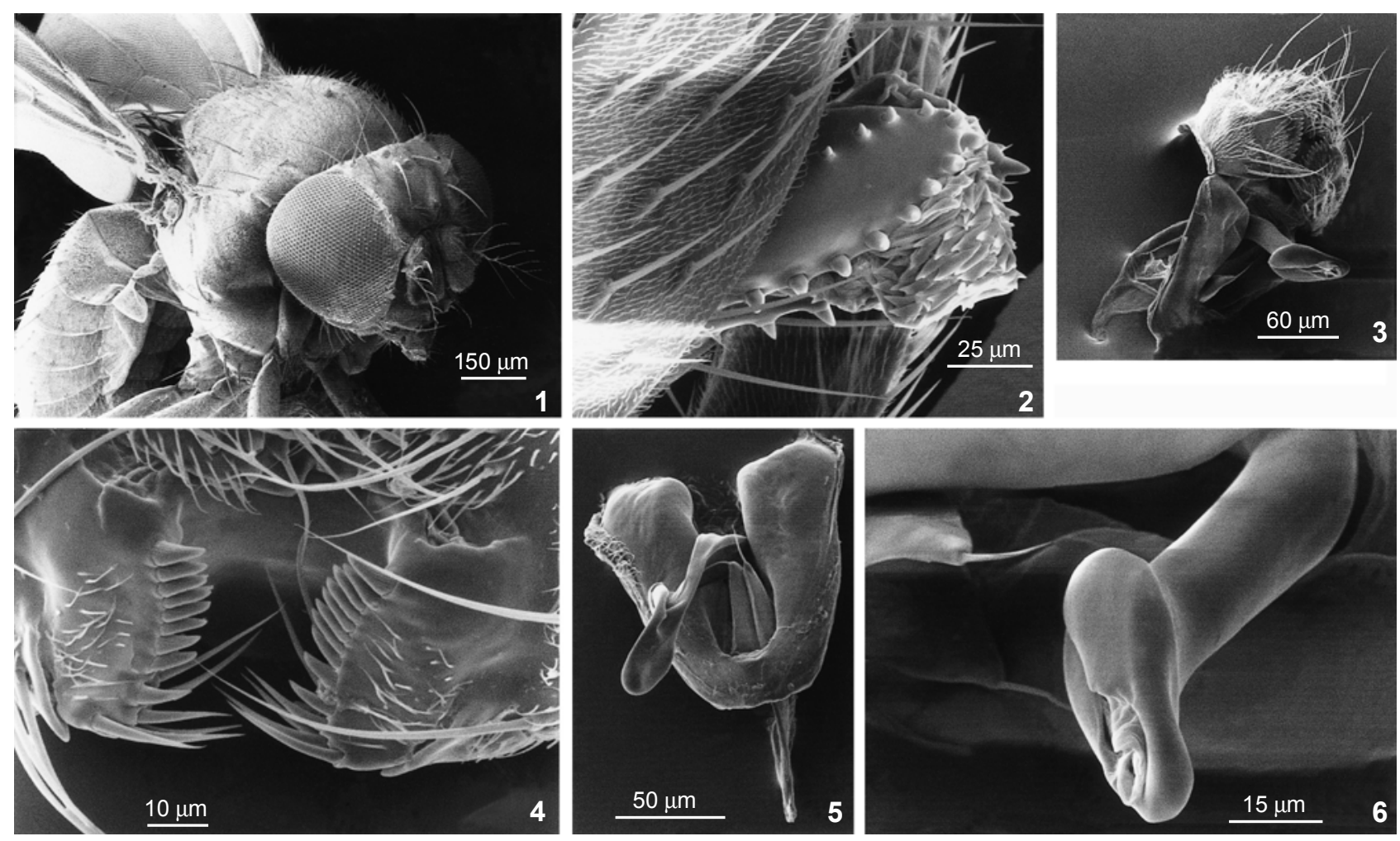

Figures 1-6. Drosophila speciosa sp. nov. (1-2) Female: (1) general view, (2) ovipositor; (3-6) male: (3) epandrium, (4) surstili; (5) hypandrium, (6) aedeagus.

tween ocellar triangle and the stripes by the eyes, grayish, forming a V-shaped spot on the front. Second orbital shorter than others, approximately intermediate to first and third orbitals. Face yellow, darker than front, with prominent carina. Palpi light brown, pollinose. One prominent oral bristle. Eyes with very short dark hairs. Thorax: mesonotum, scutellum and upper pleurae yellow. Halteres faint yellow. Acrostichal hairs in eight regular rows; two prescutellars present. Anterior scutellars bristles convergent. Sterno-pleural index about 0.5-0.9. Legs yellow, 5th segments of tarsi browned. Apical and preapical bristles on $1^{\text {st }}$ and $2^{\text {nd }}$ tibiae; preapical on third. Wings clear, slightly grayish; costal-index about 2.07 in males and 2.39 in females, $4^{\text {th }}$ vein index 1.77 in male and 1.83 in female, $5^{\text {th }}$ vein index 1.63 male and 1.60 in female. Wing length about 1,5-2,0 mm (female), 1,5-1,7 mm (male).

Abdomen. Abdomen yellow, darker than mesonotum, tergites with darker weekly interrupted posterior stripes.

Male terminalia (Figs 3-6). Epandrium (Fig. 3) with six ventral bristles: three (four) lower, two (one) median and one in an upper position. Cerci fused to epandrium (Fig. 3). Surstili with 1113 primary teeth (Fig. 4). Hypandrium shorter than epandrium (Fig. 5). Aedeagus shape slightly invaginated at distal dorsal tip (Fig. 6). Aedeagal apodeme, paramere triangular. Phallosomal index 3.0.
Female terminalia (Figs 2 and 7-9). Ovipositor plates reddish, slightly pointed apically, with 12 marginal and 3-4 discal short spines (Figs 7-9) (15-16 marginal and 3-4 discal in $D$. aguape, Fig. 10). Spermatheca brown grayish, mushroomshaped with a flat-top, slightly sclerotized, duct half-way telescoped. Puparia (Figs 11-12). Reddish brown; horn index about 0,2-0,3, each anterior spiracle with about 9-12 branches. Life cycle (at 25 degrees): larval stage about 12 days and pupal stage about seven days.

Distribution. Pará, Brazil.

Drosophila speciosa sp. nov. belongs to the bromeliae group in subgenus Drosophila. The external morphology and general shape of the male terminalia, especially the aedeagus, suggest a close relationship to D. bromelioides Pavan \& Cunha, 1947 and D. aguape Val \& Marques, 1996. However, D. speciosa differs from both of these species by its male and female terminalia and from $D$. aguape also by general coloration.

Additional specimens examined, deposited in the Museu Paraense Emílio Goeldi (MPEG), Belém, Pará, Brazil: One-hundred thirteen adults of $D$. speciosa sp. nov. collected in Theobroma speciosum flowers in the EMBRAPA/CPATU germplasm collection in Belém; four adults collected from $T$. speciosum flowers in primary forest gaps at the Caxiuanã Sci- 

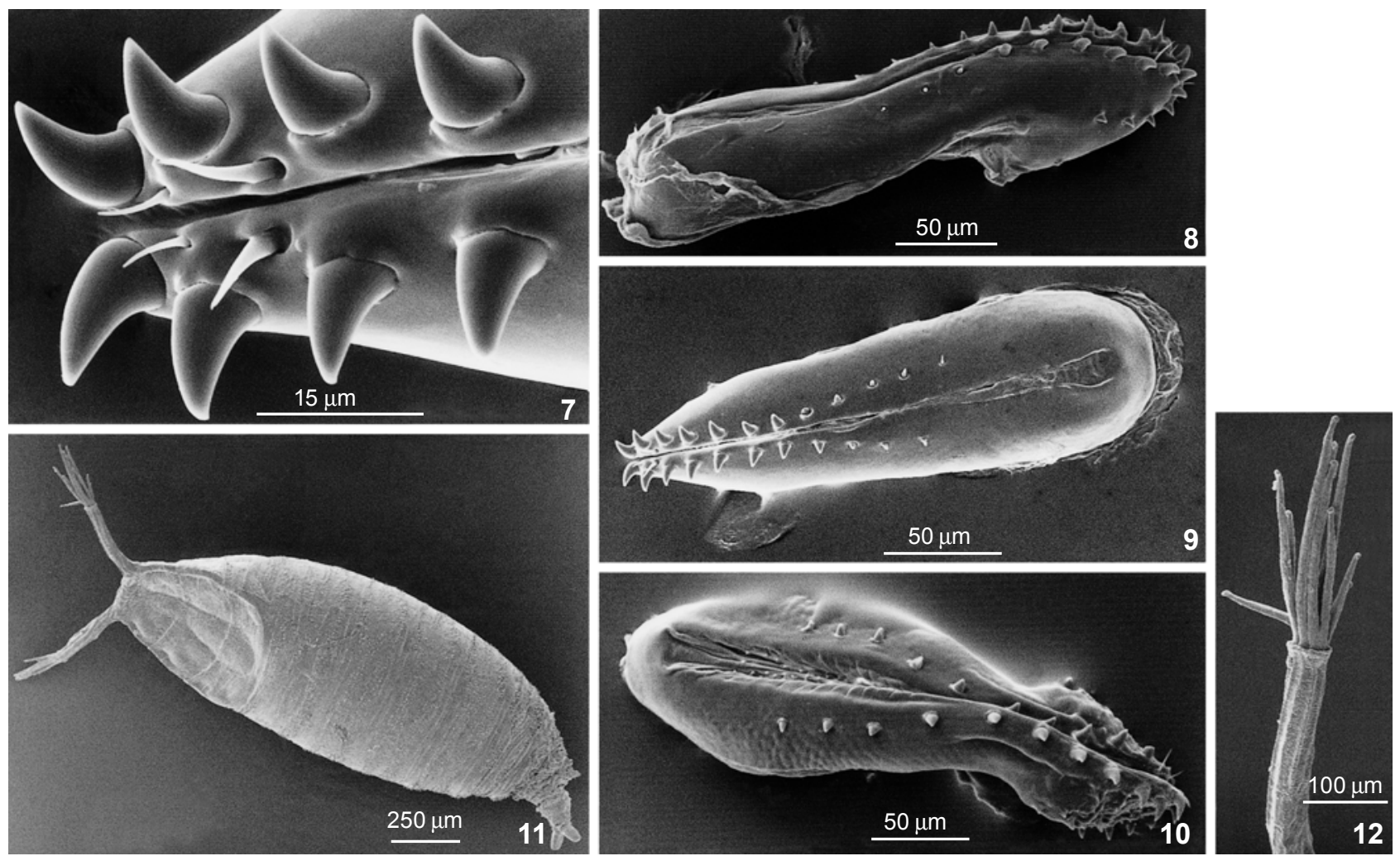

Figures 7-12. (7-9) Drosophila speciosa sp. nov., female ovipositor plates: (7) details, (8) lateral view, (9) ventral view; (10) D. aguape female ovipositor plates, ventral view; (11-12) D. speciosa sp. nov.: (11) puparia, dorsal view, (12) branches of the horn view.

entific Station; 532 individuals emerged in laboratory from Flowers collected in EMBRAPA/CPATU and four individuals raised from Theobroma speciosum flowers collected in Caxiuanã. Drosophila speciosa sp. nov. was found visiting sapromiophilic flowers of Theobroma speciosum Willd. ex Spreng. (Sterculiaceae) and Passiflora edulis Sims (Passifloraceae).

This species is named in recognition of its presumed principal host, Theobroma speciosum.

\section{ACKNOWLEDGMENTS}

We acknowledge CNPq/PNOPG and CNPq/PTU for financial support; CAPES and CNPq for scholarships to the first author; and Rita de Cássia O. Santos, Orlando Tobias, and Randy Evans for their reviews of the manuscript.

\section{REFERENCES}

KANESHIRO, K.Y. 1969. A study of the relationships of Hawaiian Drosophila species based on the external male genitalia. University Texas Publication, Austin, 6918: 55-70.

Patterson, J.T. \& W.S. Stone. 1952. Evolution in the genus Drosophila. New York, MacMillan, 610p.
SAKAI, S. 2002. Aristolochia spp. (Aristolochiaceae) pollinated by flies breeding on decomposing flowers in Panama. American Journal of Botany 89 (3): 527-534.

VAL, F.C. 1982. The male genitalia of some neotropical Drosophila: notes and illustrations. Papéis Avulsos de Zoologia, São Paulo, 34 (27): 309-347.

VAL, F.C. \& M.D. Marques. 1996. Drosophilidae (Diptera) from the Pantanal of Mato Grosso (Brazil), with the Description of a new species belonging to the Bromeliae group of the Genus Drosophila.. Papéis avulsos de Zoologia, São Paulo, 39 (11): 223-230.

Wheeler, M.R. \& M.P. Kambysellis. 1966. Notes on the Drosophilidae (Diptera) of Samoa. University of Texas Publication, Austin, 6615: 533-565.

Wheeler, M.R.; H. Takada \& D. Brncic. 1962. The Flavopilosa species group of Drosophila. University of Texas Publication, Austin, 6205: 395-413.

Received in 01.X.2003; accepted in 21.VI.2004. 